\title{
量子化学計算による酵素の反応解析
}

\author{
吉澤一成
}

\section{Analysis of Enzymatic Reactions by Quantum Chemical Calculations}

\author{
Kazunari Yoshizawa \\ Institute for Materials Chemistry and Engneering, Kyushu University; \\ 744 Motooka, Nishi-ku, Fukuoka 819-0395, Japan.
}

(Received April 12, 2012)

\begin{abstract}
Density functional theory (DFT) is now extensively used as a research tool for the investigation of structure and reactivity of biological systems; however, its high computational demands still restrict the applicability of DFT to systems of a few tens up to one hundred atoms. A combined quantum mechanical/molecular mechanical (QM/MM) approach is applicable as an important method to study whole enzyme systems more than ten thousands atoms. We have investigated methane monooxygenase, dopamenie $\beta$-monooxygenase, tyrosinase, B12 dependent diol dehydratase, etc. using DFT and QM/MM calculations. In particular, we have done some computational mutation analyses about the amino acid residues at the active site of diol dehydratase. Our DFT and QM/MM calculations can correctly describe the structures and activation barriers of intermediates and transition states in the protein environment, and therefore, we successfully revealed the catalytic role of amino acid residues at the active site of diol dehydratase. Predicted relative activities of mutants are consistent with experimentally observed reaction rates. These results encourage us to apply QM/ MM research to enzymatic reactions, functional analysis of active-site residues, and rational design of enzymes with new catalytic functions.
\end{abstract}

Key words - computational mutation; density functional method; metalloenzyme; quantum chemistry; quantum mechanical/molecular mechanical method

\section{1.はじめに}

密度汎関数計算により酵素や触媒の反応機構が詳 しく議論できるようになった. 10 年程以前には考 えられなかった進歩である.さらに量子力学と分子 力学を組み合わせた，いわゆる $\mathrm{QM} / \mathrm{MM}$ 計算によ り，1 万原子を超える酵素の大規模量子化学計算も 現実化している，本稿では，これまでに行ったメ夕 ン酸化酵素やドーパミン酸化酵素の研究，さらには B12 関連酵素を取り上げ人工変異による反応設計な どについて紹介する。ここでは，これらの研究例を 概観するとともに量子化学計算を使つた酵素研究の 将来展望について考察したい.

筆者は，恩師である福井謙一先生とノーベル賞を 分け合った，コーネル大学のロアルド・ホフマン先

九州大学先導物質化学研究所（广819-0395 福岡市西区 元岡 744 番地)

e-mail: kazunari@ms.ifoc.kyushu-u.ac.jp

本総説は, 日本薬学会第 131 年会シンポジウム S39 で 発表したものを中心に記述したものである.
生の研究室に留学する機会を得て，新たに金属酵素 の構造と反応性の理論的研究を始めることにした. それまでは， $\pi$ 共役系化合物の電子物性の研究を行 っていた。物性研究から酵素研究へと大きくシフト したのである. 現在の研究は, 研究室のメンバーの 協力の下に, 物性研究 3 割, 酵素触媒研究 7 割とい った感じであろうか. 酵素の量子化学研究を始める きっかけになったのは, Rozenzweig らによる可溶 性メタンモノオキシゲナーゼの X 線構造解析で,

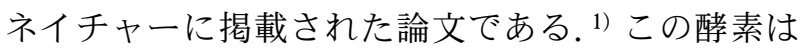
アルカン類の中でも飛び抜けて不活性なメタンを常 温常圧でメタノールに変換する. 福井先生の研究室 の名称が炭化水素物理化学講座であったということ も思い出されて, この酵素の構造と機能に強く惹か れた。当初はメタンと反応する直接の活性構造が分 かっていなかったが，そのような状況下で拡張ヒュ ッケル計算を使ってこの酵素の構造とメタンに対す る反応性の予測を行った. ${ }^{2-4)}$

量子化学の分野でも 1995 年頃から密度汎関数理 
論（DFT）が使えるようになり，筆者らはメタン モノオキシゲナーゼ，シトクローム P450，へムオ キシゲナーゼ，フェニルアラニンヒドロキシラー ゼ，ドーパミン $\beta$ モノオキシゲナーゼ，チロシ ナーゼ， ジオールデヒドラターゼ，デハロゲナーゼ などの構造活性相関の理論的研究を行うことができ た。ささらに，量子力学と分子力学を組み合わせた， いわゆる $\mathrm{QM} / \mathrm{MM}$ 計算により，1 万原子を超える 酵素の大規模量子化学計算を行った。 $Q M / M M$ 計 算を使えば不完全ながらも酵素の全原子を考慮する ことができる.

\section{2. メタン酸化酵素及び関連する触媒反応}

メタンは極めて強い C-H 結合 $(104 \mathrm{kcal} / \mathrm{mol})$, 構造の高対称性に起因する双極子モーメントの欠 如，及び低い酸性度と塩基度などに由来して極めて 反応性に乏しい炭化水素と言える. ${ }^{5,6)}$ メタンの化学 修飾は現代化学の目指す最重要課題の 1 つに数えら れている. Figure 1 に示すように, アルカンの CH 結合エネルギーと HOMO-LUMO ギャップには よい相関がある. ${ }^{7)}$ HOMO-LUMO ギャップの大き さは分子の堅さの尺度であり，メタンは極めて堅い 分子であると言える.このメタンを常温・常圧でメ タノールへと変換する酵素がメタンモノオキシゲ ナーゼ (MMO) である. ${ }^{8-11)} \mathrm{MMO}$ はメタンを唯一 のエネルギー源あるいは炭素源とするメタン資化細 菌に含まれる金属酵素である，MMOには，細胞質

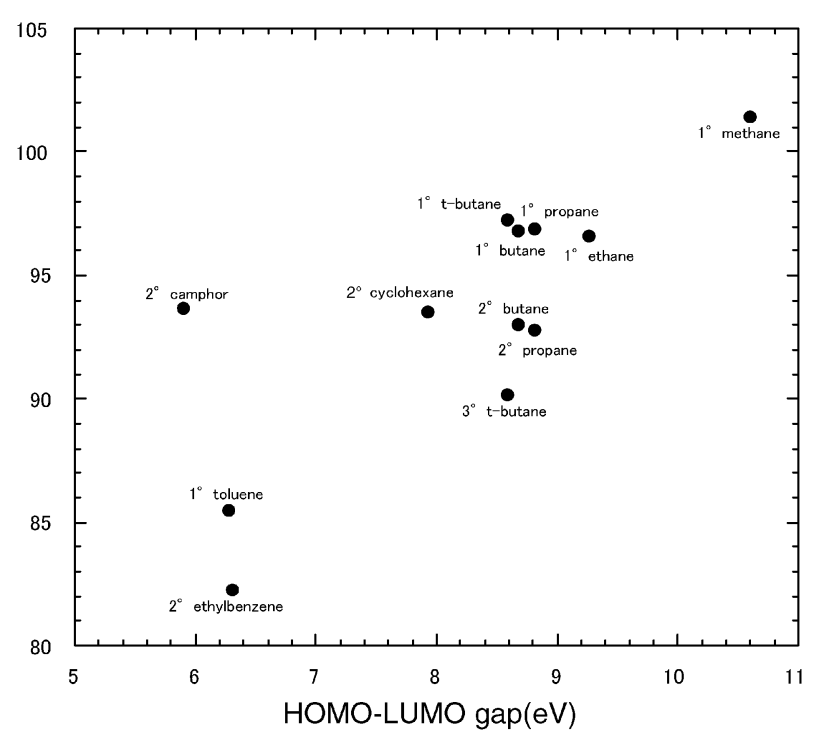

Fig. 1. C-H Bond Energies vs. HOMO-LUMO Gaps of Small Alkanes at the B3LYP/6-311++G** Level of Density Functional Theory
に存在し可溶性の $\mathrm{SMMO}$ と細胞内膜に含まれる膜 結合型の $\mathrm{pMMO}$ が知られている. sMMO の酵素 機能には鉄 2 核構造を有する活性中心が深く関与し ていることが明らかにされている.

メタンからメタノールへの反応機構のヒントは, ベルリン工科大学のグループによって研究されてい た $\mathrm{FeO}^{+}$活性種とメタンとの気相反応にあるように 思われた. ${ }^{12)}$ DFT 計算の結果，メタンは配位不飽 和な $\mathrm{FeO}^{+}$と反応し，二段階でメタノールに変換さ れることが分かった (Fig. 2).13-15)この機構では, $\mathrm{C}-\mathrm{H}$ 結合活性化の段階でラジカル種が生じない. この反応過程では 4 重項と 6 重項が関与し，このス ピンクロスオーバーにより $\mathrm{C}-\mathrm{H}$ 結合の活性化エネ ルギーが実質的に低下している，スカンジウムから 銅に至る，一連の遷移金属オキソ種のメタンに対す る反応性を計算し，鉄，ニッケル，銅がメタンーメ タノール変換に対して高い反応性と選択性を有する ことを明らかとした. ${ }^{7,15)}$

筆者はこの機構をメタンモノオキシゲナーゼに応 用しようと考えた。鉄 2 核構造を活性中心に有する 可溶性の SMMO はこれまで比較的よく研究されて いる。様々な中間体のうち，メタンと直接反応して メタノールに変換するのは $\mathrm{Q}$ と呼ばれる中間体で ある。 EXAFS 測定から中間体 Q Q は，カルボキシ レートを架橋配位子として有する $\mathrm{Fe}_{2}(\mu-\mathrm{O})_{2}$ 型のダ イヤモンド構造をとっているものと推定されてい る. ${ }^{16)}$ 中間体 Q に対する EXAFS の結果には興味深 い点がいくつか含まれている，そのうちの1つは， この 2 核構造の鉄イオンが 6 配位に飽和していない というものである. EXAFS 測定によれば，1つの 鉄には平均して 4.5 個の酸素あるいは窒素が配位し

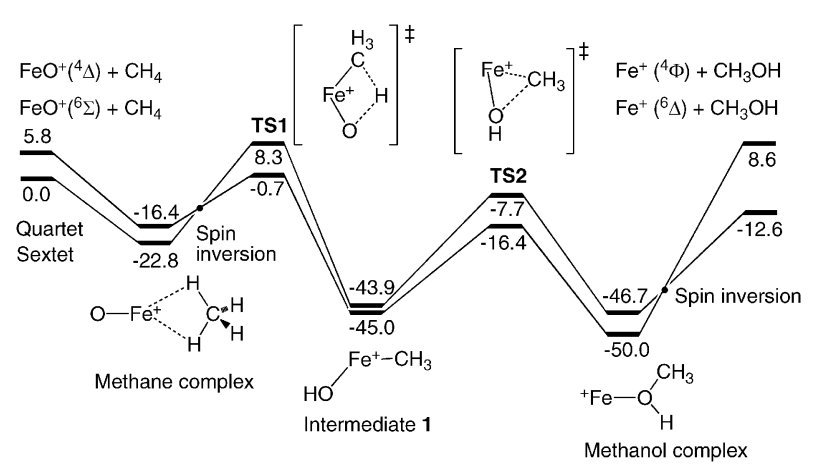

Fig. 2. Energy Diagrams (in $\mathrm{kcal} / \mathrm{mol}$ ) for the Methane Hydroxylation by $\mathrm{FeO}^{+}$in the Quartet and Sextet States 
ている，筆者らはこの中間体 $\mathrm{Q}$ に上述の非ラジカ ル機構を適用した。 反応の初期段階で，メタンは配 位不飽和の鉄イオンに弱く結合し，興味深いメタン 錯体を形成する (Fig. 3 の左の反応機構). ${ }^{7}$ ここの 後, メタンの 1 つの水素原子がオキソ種に引き抜か れヒドロキシ中間体が生成する。さらに生成したヒ ドロキシ中間体はメチル基の転位を経て，メタノー ル錯体へと変化し，これからメタノールが遊離す る.この反応機構によれば，メタンはラジカル中間 体を経ることなくメタノールへ変換される。その 後，この機構での水素引き抜き段階の速度論的同位 体効果の計算も行ったが，実験結果とよい一致を示

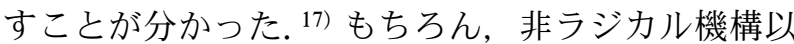
外にもいくつかの機構が提案されているが, 18-20) 実 験的な情報も少ない状況でどれが正しいものかは分 かっていない。

最近，解像度はかならずしも高くないが，膜結合 型の $\mathrm{pMMO}$ の $\mathrm{X}$ 線構造が解かれ，単核銅，二核 銅及び単核亜鉛からなる 3 つの金属活性点を持つこ とが明らかとなった。 ${ }^{21)}$ 亜鉛は結晶化緩衝液に由来 するので，筆者らは単核銅サイト及び二核銅サイト に注目し，X 線構造解析を基にした DFT 及び QM /MM 計算を行い，反応中心は二核銅活性点にある のではないかと提案している. ${ }^{22)}$ Figure 4 には最初 の中間体である $\mathrm{Cu}^{\mathrm{I}} \mathrm{Cu}^{\mathrm{II}}$ ペルオキソ種と $\mathrm{Cu}^{\mathrm{II}} \mathrm{Cu}^{\mathrm{II}}$ ペ ルオキソ種を示す。これから，さらに O-O 結合が 解離して, $\mathrm{Cu}_{2}(\mu-\mathrm{O})_{2}$ 型のジオキソ種が生成すると 考えられる。その際に銅の価数は $\mathrm{Cu}^{\mathrm{II}} \mathrm{Cu}^{\mathrm{III}}$ 及び

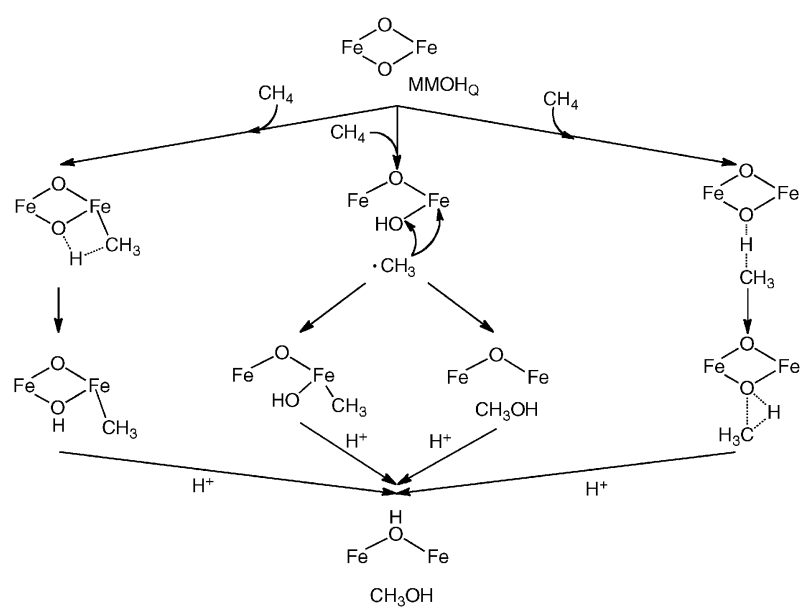

Fig. 3. Proposed Mechanisms for Methane Hydroxylation by sMMO
$\mathrm{Cu}^{\mathrm{III}} \mathrm{Cu}^{\mathrm{III}}$ となる。活性種とメタンとの反応性を調 べるために $\mathrm{C}-\mathrm{H}$ 結合解裂の活性化エネルギーを比 較した。その結果, $\mathrm{Cu}^{\mathrm{II}} \mathrm{Cu}^{\mathrm{III}}$ のジオキソ状態は比 較的容易にメタンの $\mathrm{C}-\mathrm{H}$ 結合を活性化できる。こ れに対して， $\mathrm{Cu}^{\mathrm{III}} \mathrm{Cu}^{\mathrm{III}}$ のジオキソ状態は $\mathrm{C}-\mathrm{H}$ 結合 に対する反応活性が低く，C-H 結合を解裂できな いことが分かった。

\section{3. ドーパミン酸化酵素の活性種と反応機構}

ドーパミン $\beta$ モノオキシゲナーゼ (DBM) はドー パミンをノルエピネフリンに水酸化する酵素であ り，生命維持において非常に重要な役割を果たして いる. ${ }^{23-25)}$ 反応物であるドーパミンは血圧を低下さ せ，生成物であるノルエピネフリンは血圧を上昇さ せる作用があるため，DBM の活性阻害は高血圧症 の治療法として注目されている.DBM はサブユニ ット当たり 2 つ銅原子を含んだ二量体や四量体を 形成している．Figure 5 に示すように，DBM は反 応の際に 2 つ電子とプロトンをアスコルビン酸か ら受け取ると考えられている。銅イオン間にスピン 結合が観測されないため，2つの銅イオンは少なく とも $4 \AA$ 以上離れている。この結果は，チロシ ナーゼやへモシアニンにみられる二核構造が DBM には存在しないことを示唆する。DBM の 2 つの銅 中心は別々の役割を担う。第一のサイト $\left(\mathrm{Cu}_{\mathrm{A}}\right)$ は アスコルビン酸と結合し，アスコルビン酸から第二 のサイト $\left(\mathrm{Cu}_{\mathrm{B}}\right)$ へ電子伝達を行い, $\mathrm{Cu}_{\mathrm{B}}$ 中心は基 質の結合や水酸化を行うと言われている.

この $\mathrm{Cu}_{\mathrm{B}}$ サイトの活性種として，銅ヒドロパー オキソ種，銅スーパーオキソ種，銅オキソ種が提案 (a)

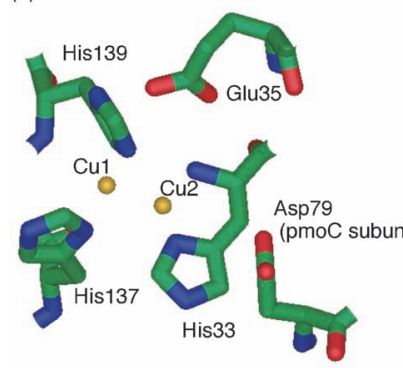

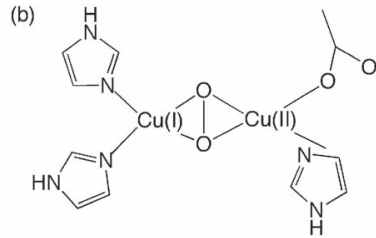

(c)

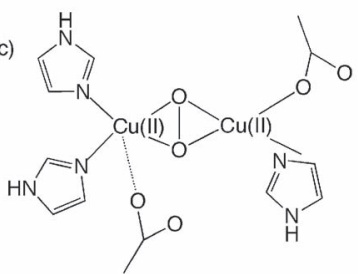

Fig. 4. The Dicopper Site of pMMO and Its Possible Peroxo Forms

(a) X-ray structure, (b) $\mathrm{Cu}^{\mathrm{I}} \mathrm{Cu}^{\mathrm{II}}$ peroxo species, and (c) $\mathrm{Cu}^{\mathrm{II}} \mathrm{Cu}^{\mathrm{III}}$ peroxo species. 
されている (Fig. 6).ここでは銅オキソ種と呼称 しているが，そのスピン密度分布から， $\mathrm{Cu}^{\mathrm{III}}-\mathrm{O}^{2-}$ というよりは $\mathrm{Cu}^{\mathrm{II}}-\mathrm{O}^{-}$がより妥当な電子配置と考 えられる。現在までにこれらの活性種による様々な 反応機構が提案されているが，その反応機構を十分 説明するには至っていない。このような状況下で, 銅ヒドロパーオキソ種が活性種ではないかと考えら れたり，また，DFT 計算により銅スーパーオキソ

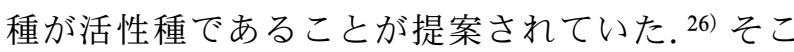
で，筆者らは DBM の 3 種の活性種の構築を行い, それらの反応性を理論的に研究することにし た. ${ }^{27,28)}$ この酵素の X 線構造解析はなされていない
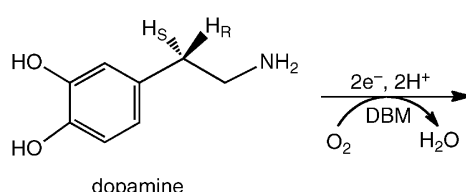

dopamine

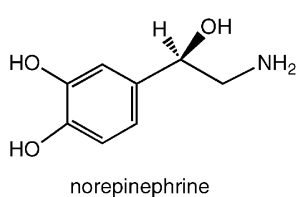

norepinephrine
Fig. 5. Hydroxylation of Dopamine to Norepinephrine

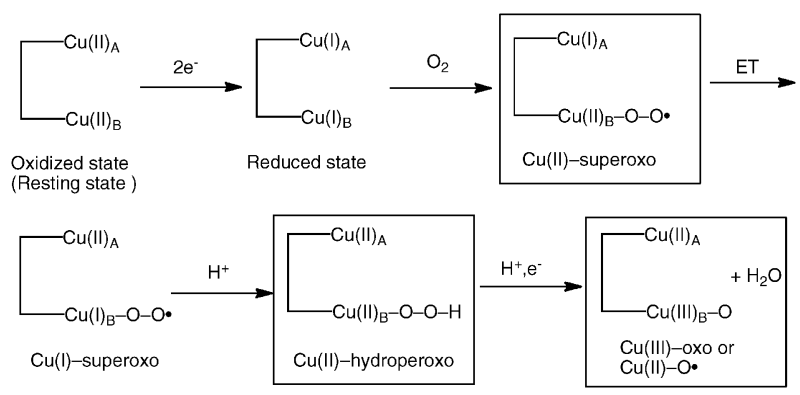

Fig. 6. Possible Intermediates for Dopamine $\beta$-monooxygenase
ので，親類筋に当たる PHM（peptidylglycine $\alpha$ hydroxylating monooxygenase) の X 線構造解析を 基にして，DBMの 3 次元構造を構築した。 DBM と PHM はアミノ酸配列において $30 \%$ の相同性を 持つ．2つの酵素のアミノ酸配列にこの程度の相同 性があれば，構造の分かっている酵素の 3 次元構造 に基づいて，構造の分かっていない酵素の構造を木 モロジーモデリングから再現できる。ささらに量子力 学と分子力学を融合させた $\mathrm{QM} / \mathrm{MM}$ 法の 1 つであ る ONIOM 法29)により DBM の構造（約 5000 原子） を最適化した。これにより，水素原子を含むすべて の原子の 3 次元構造が X 線構造解析の結果を使う ことなく構築できた. ${ }^{27,28)}$

Figure 7 は計算から得た DBM の 3 種の活性種を 示す。ドーパミンのベンジル位の水素引き抜きの活 性化エネルギーを計算したところ，パーオキソ種は $40 \mathrm{kcal} / \mathrm{mol}$ ，スーパーオキソ種は $23 \mathrm{kcal} / \mathrm{mol}$ ，才 キソ種は $5 \mathrm{kcal} / \mathrm{mol}$ であることが分かった。この 結果から，スーパーオキソ種やパーオキソ種は真の 活性種の前駆体ではないかと考えられる。この活性 サイトでは基質のドーパミンを水素結合ネットワー クにより固定し，立体特異的な反応が可能になって いる．DBM の銅酸素活性種によるドーパミン水酸 化の反応機構を Fig. 8 に示す。はじめに銅酸素活 性種がドーパミンのベンジル位の水素原子を引抜 き，ラジカル中間体を形成する。ベンジルラジカル は比較的安定な遊離基であるため，この活性化エネ ルギーが低いのは妥当な結果である。生じたベンジ ルラジカルがヒドロキシル基と再結合し，生成物錯
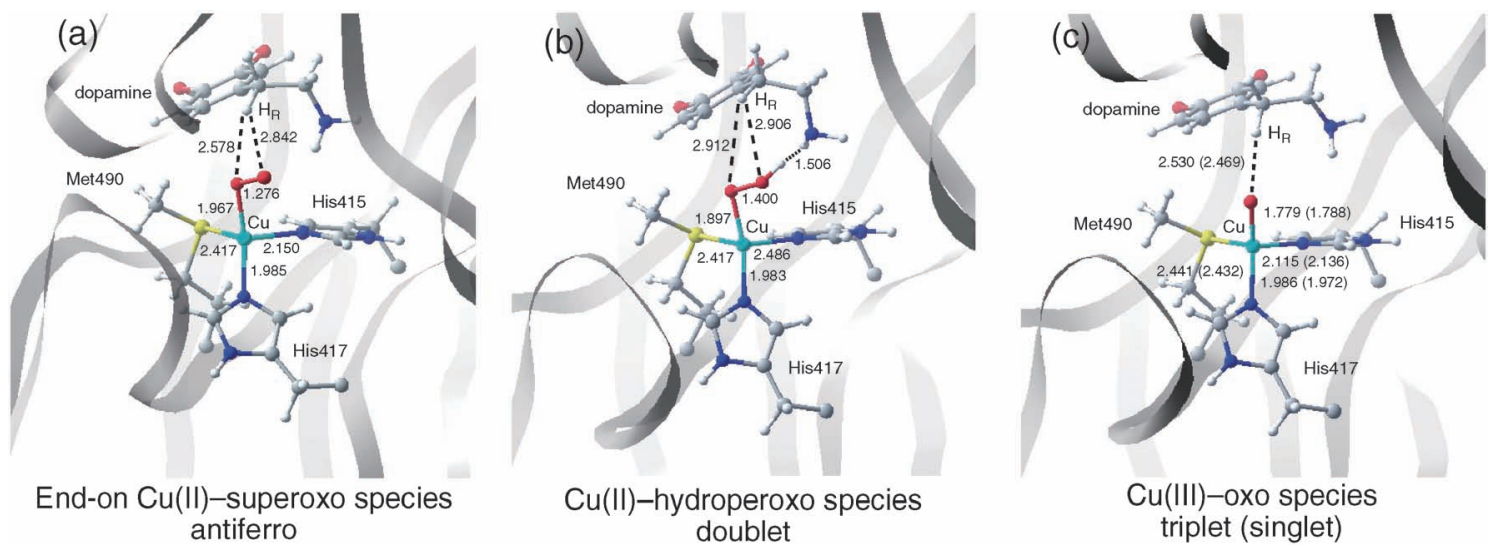

Fig. 7. QM/MM-optimized Structures for (a) End-on $\mathrm{Cu}^{\mathrm{II}}$-superoxo Species, (b) $\mathrm{Cu}^{\mathrm{II}}$-hydroperoxo Species, and (c) $\mathrm{Cu}^{\mathrm{II}}-\mathrm{oxo}$ (or $\left.\mathrm{Cu}^{\mathrm{II}}-\mathrm{O}^{*}\right)$ Species 


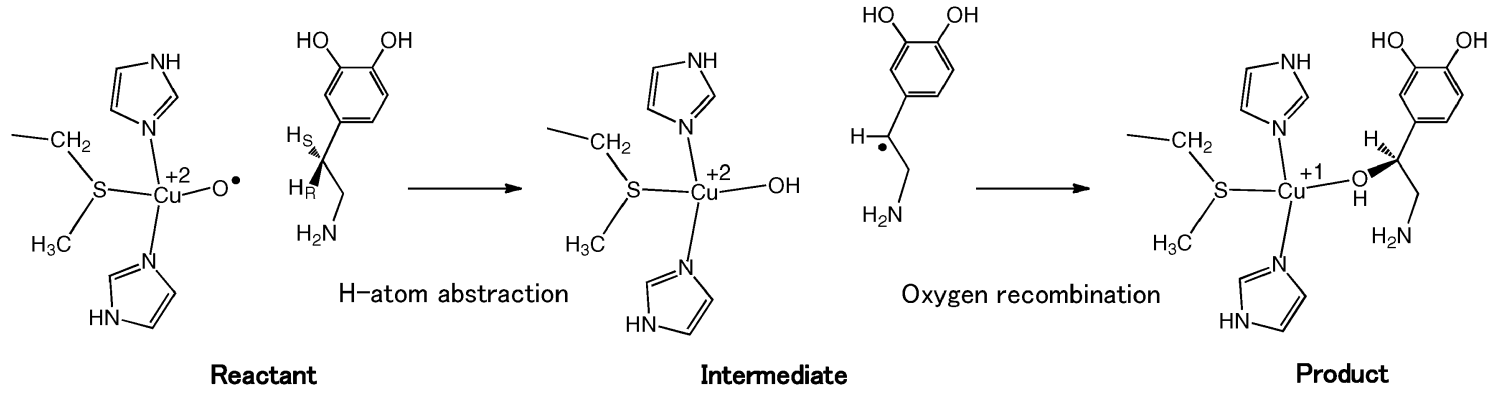

Fig. 8. Possible Mechanism for the Conversion of Dopamine to Norepinephrine

体が生じる，最近，伊東らは単核銅錯体による様々 な基質の酸化反応を観測し，その活性種は銅オキソ 種ではないかと報告している. ${ }^{30)}$

量子化学計算では実験で捕捉することの困難な不 安定中間体や遷移状態の構造とエネルギーを予測す ることができる．特筆すべきは，QM/MM 計算に よれば X 線構造解析の行われていない酵素につい てもその詳細な 3 次元構造が得られ, 反応機構の研 究が可能になる点である.これは最近の量子化学計 算の進歩を示す一例である．膜結合型の酵素のよう に構造解析が困難な酵素の構造活性相関の研究に, 量子化学計算は有効なツールとなる.

\section{4. チロシナーゼの反応機構}

メラニンは生体内で紫外線を吸収し, 細胞を保護 する働きをする重要な色素である。このメラニン生 成は，まず，チロシンがチロシナーゼによりドーパ キノンに転化されることで始まる. ${ }^{31)}$ ドーパキノン は化学的反応性が高いので, 酵素の力を借りること なく次々と酸化，重合し，メラニンとなる。このよ うに，チロシナーゼはチロシンをドーパキノンに転 化させる役割を持つメラニン合成に必要な酸化酵素 である，杉山らはチロシナーゼの結晶化に成功し， $\mathrm{X}$ 線構造解析により酵素の三次元構造を明らかに

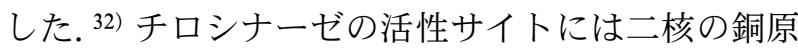
子が存在し，各銅原子に対してそれぞれヒスチジン が 3 つ配位していることがわかる。 また，それらの ヒスチジンは， $\alpha$-ヘリックス及び $\beta$-シート構造を とつているため, タンパク質内に強く固定されてい る。しかし, His54 だけは $\alpha$-ヘリックス構造も $\beta$ シート構造もとっておらず，他のヒスチジンに比べ 構造による束縛が少ないため，その役割が注目され ている. 本研究では, チロシナーゼの X 線構造解 析を基に大規模な量子化学計算（約 4300 原子）を
行い, その反応機構を詳細に議論した. ${ }^{33)}$

まず，チロシナーゼの X 線構造解析を基に計算 モデルを構築した。最初に，酵素反応とは直接関係 しない ORF タンパクと硝酸イオンは除外した．酵 素の原子数は約 4300 個であり, 活性サイトの原子 数は約 100 個である。酵素全体を，量子力学計算の みで計算するのは非常に困難であるため, QM/ $\mathrm{MM}$ 法を用いた。酵素の総電荷は+2, スピン多重 度は開殼 1 重項状態を考慮した. Figure 9 に計算に より求めたチロシナーゼの活性中心に酸素分子が付 加したパーオキソ体の構造を示す。この構造は杉山 らの X 線構造解析の結果とよく一致している.

計算により得られたチロシナーゼの反応機構を Fig. 10 に示す.まず，チロシンがチロシナーゼの 活性サイトに配位して $\mathbf{1}$ を形成する. 次に, チロシ ンの水酸基の水素がチロシナーゼのペルオキソ基へ 転移して 2 を形成する．さらに，ペルオキソ基が開 裂して 3 を形成する。 そして, 酸素のラジカルとフ エニル基のラジカルが結合して 4 を形成する，その 後, フェニル基の水素がヒスチジン残基へ転移して 5 を形成する。最後に，His54 へ転移した水素が水 酸基へ転移して 6 を形成する。 $\mathrm{QM} / \mathrm{MM}$ 計算によ り，このような詳細な反応解析が可能になる。ペル オキソ基の開裂反応 $(\mathbf{2} \rightarrow \mathbf{3})$ が律速段階で, 活性化 エネルギーは約 $14.9 \mathrm{kcal} / \mathrm{mol}$ であることが分かっ た.この活性化エネルギーから推定される反応速度 定数は，実験から得られたものとよく一致している.

\section{5. 計算ミューテーションの可能性}

ビタミン B 12 は生体内に取り込まれると，アデ ノシルコバラミンに変換され, 十数種の酵素の補酵 素として働くことが知られている. このうちジオー ルデヒドラターゼは，1,2-プロパンジオールなどの 主に炭素数 4 以下のジオールの脱水反応を触媒する 

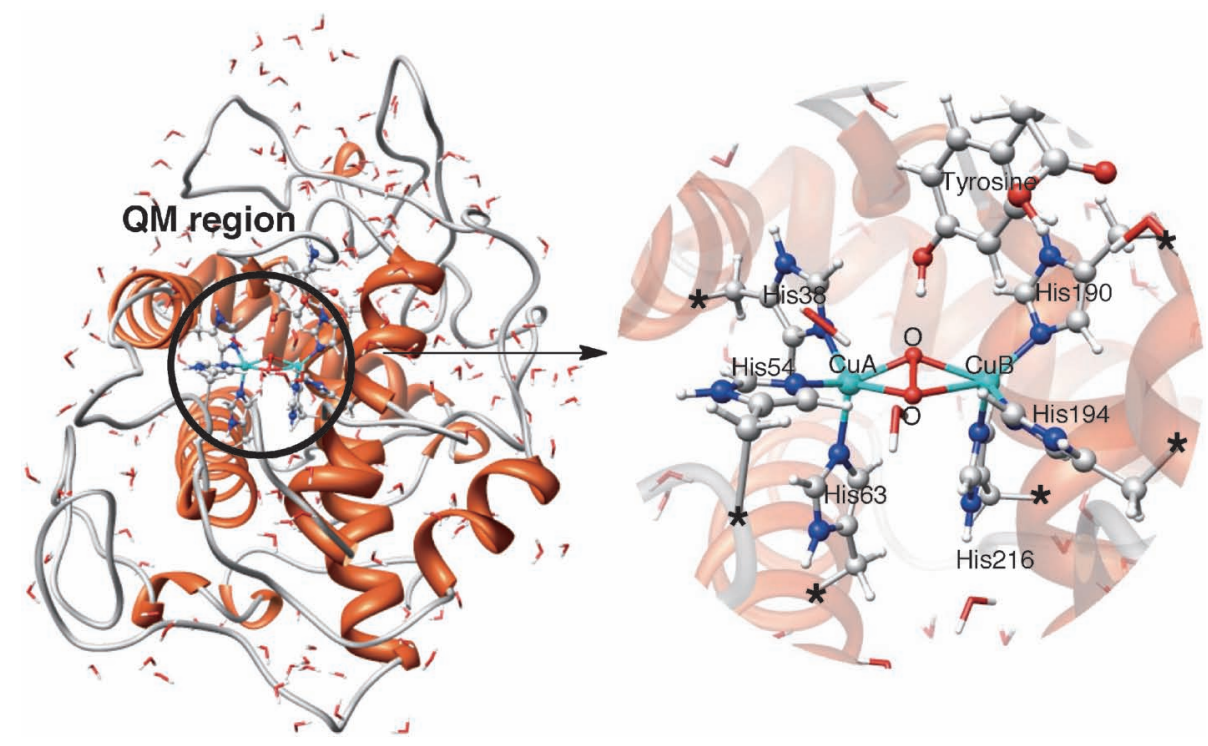

Fig. 9. QM/MM-optimized Structure for the Peroxo Species of Tyrosinase
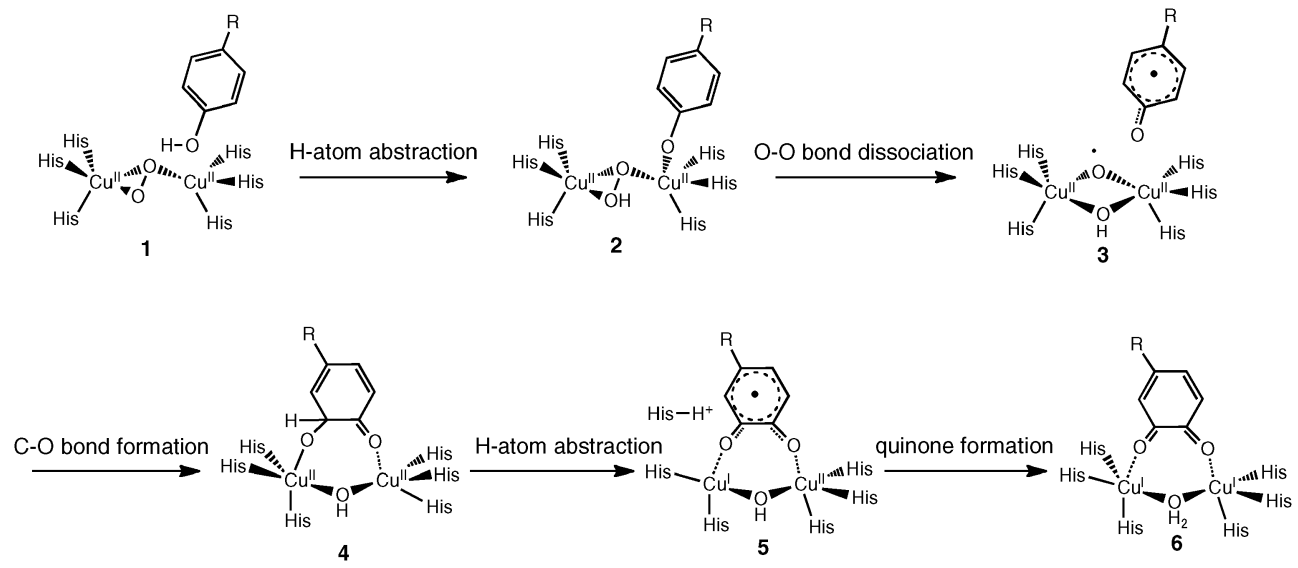

Fig. 10. Possible Mechanism for Tyrosine to Dopaquinone by Tyrosinase

酵素である．この酵素による反応は，アデノシルコ バラミン中の $\mathrm{Co}-\mathrm{C}$ 結合が均等に開裂することによ り始まる (Fig. 11). ${ }^{34)}$ これにより生じたアデノシ ルラジカルが基質の 1 位の炭素から水素を引き抜き,

1,2-diol radical が生成する. この後, 水酸基の転移 から 1,1-diol radical を経てアルデヒドと水分子に 分解される.この酵素の発見以来, 1970 年代後半 までに集中的に研究がなされ, 以上のような大まか な反応機構や, 反応全体の同位体効果 $\left(\mathrm{k}_{\mathrm{H}} / \mathrm{k}_{\mathrm{D}}=10\right)$ より，反応の律速段階は水素引き抜きであるという ことが分かっている. 加えて, $\mathrm{K}^{+}$又はこれと同程 度のイオン半径を持つモノカチオンが, ホロ酵素の 形成及び酵素反応の進行に必須であることが知られ ている。 (a)<smiles>CC(C)(C)OCC=CC=[GeH2]</smiles>

(b)

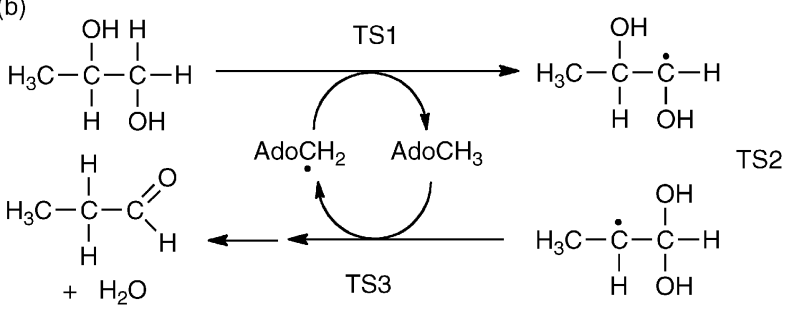

Fig. 11. Minimal Reaction Mechanism of Diol Dehydratase (a) Homolytic cleavage of the $\mathrm{Co}-\mathrm{C}$ bond in adenosyl cobalamin. (b) Dehydration by the enzyme. AdoCH $\mathrm{C}_{2}=$ adenosyl group. TS=transition state. 
虎谷らはジオールデヒドラターゼの X 線構造解 析を行い, 基質 1,2-プロパンジオールはアデノシル コバラミン中の Co 原子から $11.7 \AA$ の距離にある $\mathrm{K}^{+}$イオンに配位していることを見い出した. ${ }^{34)}$ 筆 者のグループではこの $\mathrm{X}$ 線構造に基づき，全原子 （約 13500 原子）を含む現実モデルを構築し，QM/ $\mathrm{MM}$ 計算を用いてこの反応の理論的解析を行っ た. ${ }^{35)}$ さらに，活性部位アミノ酸残基の反応への寄 与を推定するため, 活性部位残基のいくつかを置換 することで変異体モデルを構築し，それらの触媒機 能を考察した. ${ }^{36}$

この反応において重要なアミノ酸残基と考えられ てきた His143を Ala に置換した変異体 His143Ala 及び, Glu170を置換した Glu170Gln, Glu170Ala，さ らに Glu170 と Glu221 の両方を置換した Glu170Ala /Glu221Ala の 4つの変異体についてその触媒機構 を明らかにした。 Figure 12 に QM/MM 計算により 得られた 4 つの変異体の構造を示す。これらの変異 体についても，野生型と同様に基質から 1,1-diol radical への転換は水素引き抜きと水酸基転移の二 段階で進行すると考え，Table 1 に野生型とこれら の変異型酵素の反応活性をまとめた. ${ }^{36,37)}$ Glu170Gln
変異体での水酸基転移の活性化エネルギー（TS2） は $17.4 \mathrm{kcal} / \mathrm{mol}$ となり，野生型での活性化エネル ギー $11.5 \mathrm{kcal} / \mathrm{mol}$ に比べて，大きく上昇すること が判明した。実験的にもこの変異体は野生型の $1 \%$ 以下の活性しかないことが知られており，この高い 活性障壁が反応の進行を妨げていると考えられる. 計算から得られた構造から，野生型においては Glu170 が 1 位の水酸基からのプロトンを引き抜く ことで遷移状態を安定する（pull effect）のに対し て, Glu143Gln 変異体では導入された Gln は弱い 塩基であるため基質との相互作用が弱い。これが変 異体での反応性低下の直接的原因であることが判明 した.

Table 1. Calculated Barrier Heights $(\mathrm{kcal} / \mathrm{mol})$ in the Catalysis of Diol Dehydratase and Its Mutants

\begin{tabular}{lcccl}
\hline \hline & TS1 & TS2 & TS3 & relative activity $(\exp )$ \\
\hline Wild type & 13.6 & 11.5 & 17.9 & $1.0(1.0)$ \\
His143Ala & 11.7 & 16.4 & 19.6 & $6.3 \times 10^{-2}\left(1.6 \times 10^{-2}\right)$ \\
Glu170Gln & 12.5 & 17.4 & 21.6 & $2.5 \times 10^{-3}\left(2 \times 10^{-4}\right)$ \\
Glu170Ala & 10.0 & 11.4 & 20.9 & $7.6 \times 10^{-3}\left(<1 \times 10^{-4}\right)$ \\
Glu170Ala/ & 15.7 & 23.4 & 14.8 & $4.1 \times 10^{-9}$ (N.A.) \\
Glu221Ala & & & &
\end{tabular}
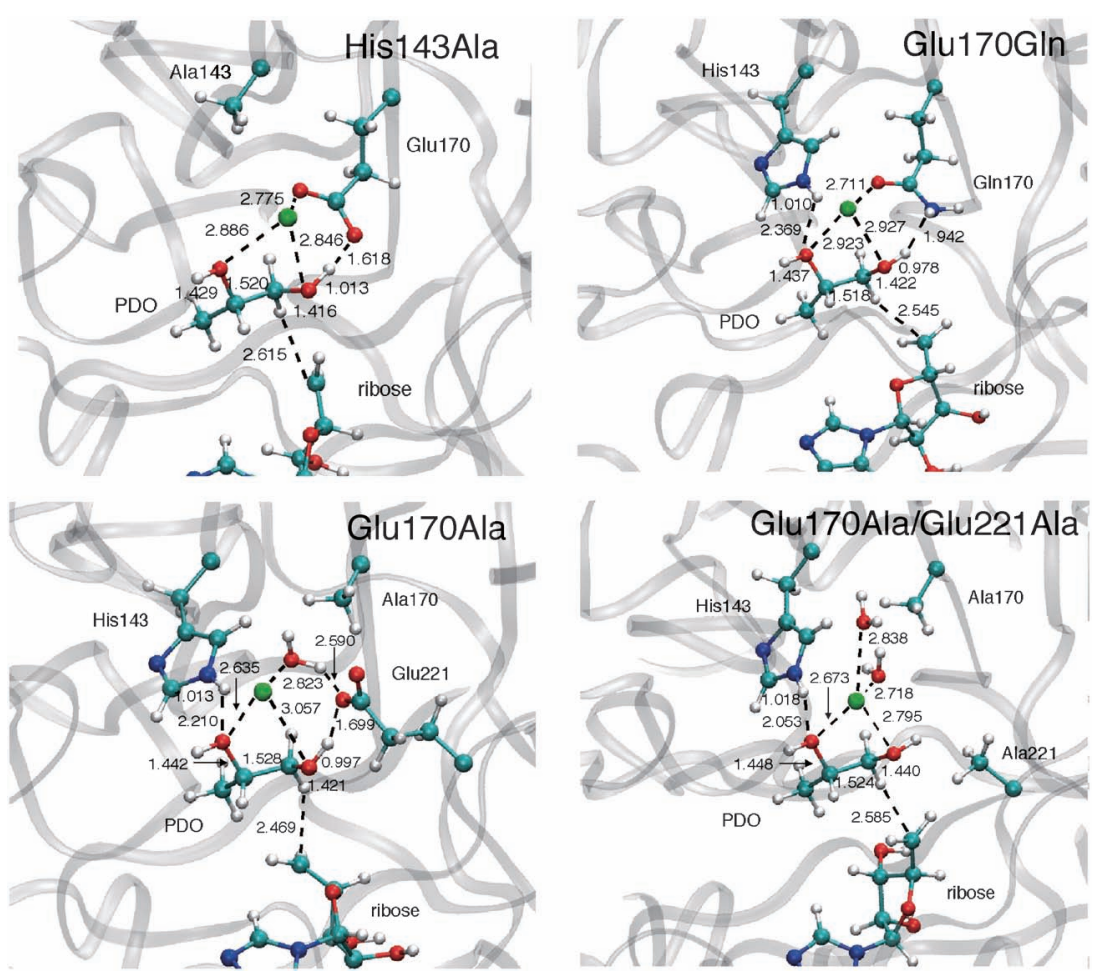

Fig. 12. QM/MM-optimized Structures of Mutants of Diol Dehydratase $\mathrm{PDO}=$ propane diol. 


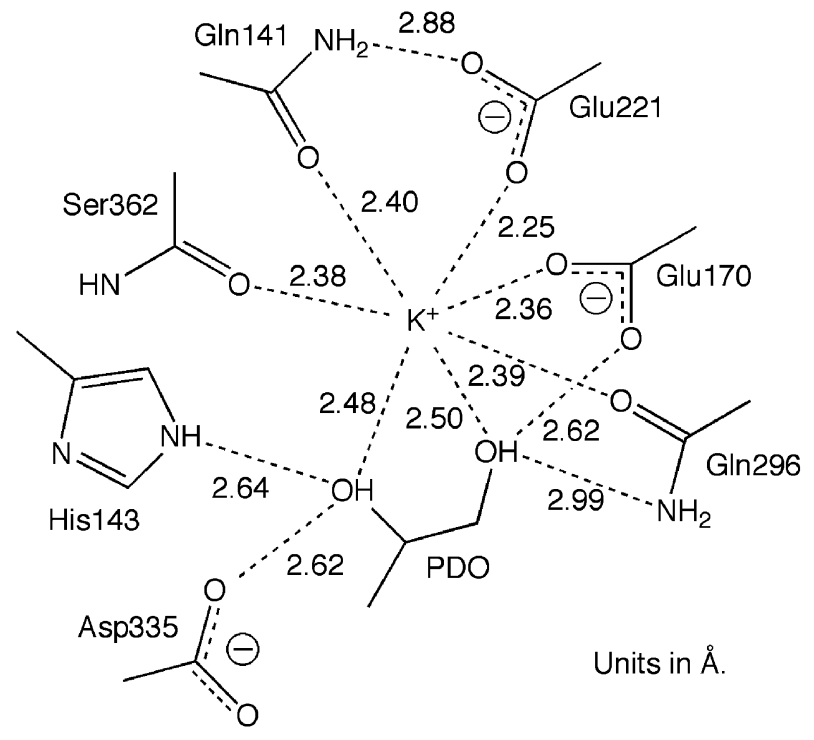

Fig. 13. X-ray Structure of the Substrate Binding Site of Diol Dehydratase

これまで行った $\mathrm{QM} / \mathrm{MM}$ 計算によるジオールデ ヒドラターゼの活性中心における $\mathrm{K}^{+}-\mathrm{O}$ の平均結 合距離は $2.8 \AA$ であった。一方，X線結晶構造にお けるそれは $2.4 \AA$ であり (Fig. 13)，0.4 ^̊という 大きな違いがみられた。この結果から, 筆者らは活 性中心の金属イオンは $\mathrm{K}^{+}$ではなく, 別の金属イオ ンなのではないかと考え, $\mathrm{QM} / \mathrm{MM}$ 計算を用いて 金属イオンの同定を行った. 金属イオンとしては $\mathrm{K}^{+}$と周期表で近隣に位置する $\mathrm{Ca}^{2+}, \mathrm{Na}^{+}, \mathrm{Mg}^{2+}$ を考えた。 Table 2 に示すのは $\mathrm{QM} / \mathrm{MM}$ 計算によ つて最適化された活性中心の金属イオンと配位酸素 の結合距離とRMS（実験值と計算值の誤差）であ る.38)これまで中心金属と考えられてきた $\mathrm{K}^{+}$の場 合における RMS は 0.49 であったが, $\mathrm{Ca}^{2+}$ の場合 の RMS が 0.11 と $\mathrm{K}^{+}$の場合よりも小さくなつた. また, $\mathrm{Na}^{+}$と $\mathrm{Mg}^{2+}$ の場合は $\mathrm{Gln} 141$ が金属イオン に配位せず六配位構造をとつたため， RMS が大き くなった．この計算結果から中心金属は $\mathrm{Ca}^{2+}$ では ないかと提案した. 最近, 虎谷らによるEDTAの 吸着実験によって金属イオンは $\mathrm{Ca}^{2+}$ であることが 確認された. ${ }^{39)} こ の$ 結果に基づいて, 本酵素の反応 性の再検討も行っている. ${ }^{40)}$ その結果については改 めて報告することにする.

\section{6. おわりに}

以上のように, いくつかの酵素を対象とした DFT 及び $\mathrm{QM} / \mathrm{MM}$ 計算により, 反応活性種の推定, 反
Table 2. QM/MM Optimized Metal-Oxygen Bond Lengths (A) in the Substrate-binding Site

\begin{tabular}{llllll}
\hline \hline & $\mathrm{K}^{+}$ & $\mathrm{Na}^{+}$ & $\mathrm{Mg}^{2+}$ & $\mathrm{Ca}^{2+}$ & X-ray \\
\hline O1(PDO) & 3.022 & 2.795 & 2.309 & 2.683 & 2.50 \\
O2(PDO) & 2.983 & 2.642 & 2.206 & 2.602 & 2.48 \\
Gln141 & 3.278 & 5.441 & 3.908 & 2.552 & 2.40 \\
Glu170 & 2.661 & 2.268 & 2.069 & 2.296 & 2.36 \\
Glu221 & 2.575 & 2.270 & 2.030 & 2.298 & 2.25 \\
Gln296 & 2.751 & 2.334 & 2.119 & 2.389 & 2.39 \\
Ser362 & 2.649 & 2.593 & 2.174 & 2.370 & 2.38 \\
RMS & 0.49 & 1.15 & 0.61 & 0.11 & \\
\hline
\end{tabular}

a RMS errors from experimental values.

応機構の提案, 活性部位アミノ酸残基の評価を行う ことができた．X 線構造解析や分光測定などの実 験から不安定な反応活性種の推定を行うことは困難 なため, 量子化学計算によるこれらの研究は極めて 有効である. 特に, ジオールデヒドラターゼについ ては量子化学計算に基づく酵素変異という新しい試 みに挑戦し, 活性部位アミノ酸残基の機能解析と変 異型酵素の活性予測を行った。 その予測は実際に構 築した変異型酵素の活性測定の結果とよい一致を示 した.これらの成果は, 量子化学による精密反応機 構の研究を大いに勇気づけるものである. 近い将 来, 量子化学的アプローチによる創薬研究も可能に なるのではないかと期待される。次世代スパコン 「京」により, 酵素全体を量子力学的に取り扱うこ とが可能になれば, 計算精度と信頼性は著しく向上 すると期待される.

謝辞本研究を推進するにあたり, 科学研究費 補助金, 九州大学 G-COE プロジェクト, ナノテク 支援プロジェクト, 統合物質創製化学推進事業, JST-CREST など文部科学省関連の研究支援に厚く 御礼申し上げる.

\section{REFERENCES}

1) Rosenzweig A. C., Frederick C. A., Lippard S. J., Nordlund P., Nature, 366, 537-543 (1993).

2) Yoshizawa K., Hoffmann R., Inorg. Chem., 35, 2409-2410 (1996).

3) Yoshizawa K., Yamabe T., Hoffmann R., New J. Chem., 21, 151-161 (1997).

4) Yoshizawa K., Ohta T., Yamabe T., 
Hoffmann R., J. Am. Chem. Soc., 119, 12311 -12321 (1997).

5) Yoshizawa K., Ohta T., Yamabe T., Nippon Kagaku Kaishi, 1998, 451-459 (1998).

6) Yoshizawa K., Kagaku Kogyo, 50, 552-561 (1999).

7) Yoshizawa K., Acc. Chem. Res., 39, 375-382 (2006)

8) Lippard S. J., Angew. Chem., Int. Ed., 27, 344-361 (1988).

9) Feig A. L., Lippard S. J., Chem. Rev., 94, 759 -805 (1994).

10) Lipscomb J. D., Annu. Rev. Microbiol., 48, 371-391 (1994).

11) Wallar B. J., Lipscomb J. D., Chem. Rev., 96, 2625-2657 (1996).

12) Schröder D., Schwarz H., Angew. Chem., Int. Ed., 34, 1973-1995 (1995).

13) Yoshizawa K., Shiota Y., Yamabe T., Chem. Eur. J., 3, 1160-1169 (1997).

14) Yoshizawa K., Shiota Y., Yamabe T., J. Am. Chem. Soc., 120, 564-572 (1998).

15) Shiota Y., Yoshizawa K., J. Am. Chem. Soc., 122, 12317-12326 (2000).

16) Shu L., Nesheim J. C., Kauffmann K., Münck E., Lipscomb J. D., Que L., Science, 275, 515 -518 (1997).

17) Yoshizawa K., Yumura T., Chem. Eur. J., 9, 2347-2358 (2003).

18) Siegbahn P. E. M., Crabtree R. H., J. Am. Chem. Soc., 119, 3103-3113 (1997).

19) Basch, H., Mogi K., Musaev D. G., Morokuma K., J. Am. Chem. Soc., 121, 7249-7259 (1999)

20) Dunietz B. D., Beachy M. D., Cao Y., Whittington D. A., Lippard S. J., Friesner R. A., J. Am. Chem. Soc., 122, 2828-2839 (2000) .

21) Lieberman R. L., Rosenzweig A. C., Nature, 434, 177-182 (2005).

22) Yoshizawa K., Shiota Y., J. Am. Chem. Soc., 128, 9873-9881 (2006).
23) Ljones T., Skotland T., "Copper Proteins and Copper Enzymes," Vol. 2, ed. by Lontie R., CRC Press, Boca Raton, 1984, pp. 131-157.

24) Eipper B. A., Stoffers D. A., Mains R. E., Annu. Rev. Neurosci., 15, 57-85 (1992).

25) Klinman J. P., Chem. Rev., 96, 2541-2561 (1996).

26) Chen P., Solomon E. I., J. Am. Chem. Soc., 126, 4991-5000 (2004).

27) Kamachi T., Kihara N., Shiota Y., Yoshizawa K., Inorg. Chem., 44, 4226-4263 (2005).

28) Yoshizawa K., Kihara N., Kamachi T., Shiota Y., Inorg. Chem., 45, 3034-3041 (2006).

29) Maseras F., Morokuma K., J. Comput. Chem., 16, 1170-1179 (1995).

30) Kunishita A., Ishimaru H., Nakashima S., Ogura T., Itoh S., J. Am. Chem. Soc., 130, 4244-4245 (2008).

31) Solomon E. I., Sundaram U. M., Machonkin T. E., Chem. Rev., 96, 2563-2605 (1996).

32) Matoba Y., Kumagai T., Yamamoto A., Yoshitsu H., Sugiyama M., J. Biol. Chem., 281, 8981-8990 (2006).

33) Inoue T., Shiota Y., Yoshizawa K., J. Am. Chem. Soc., 130, 16890-16897 (2008).

34) Toraya T., Chem. Rev., 103, 2095-2127 (2003)

35) Kamachi T., Toraya T., Yoshizawa K., J. Am. Chem. Soc., 126, 16207-16216 (2004).

36) Kamachi T., Toraya T., Yoshizawa K., Chem. Eur. J., 13, 7864-7873 (2007).

37) Toraya T., Kamachi T., Yoshizawa K., Seikagaku, 80, 132-138 (2008).

38) Kamachi T., Takahata M., Toraya T., Yoshizawa K., J. Phys. Chem. B, 113, 8435-8438 (2009)

39) Toraya T., Honda S., Mori K., Biochemistry, 49, 7210-7217 (2010).

40) Kamachi T., Doitomi K., Takahata M., Toraya T., Yoshizawa K., Inorg. Chem., 50, 2944-2952 (2011). 